\title{
Hurricane Omar Waves Impact on the West Coast of the Guadeloupe Island, October 2008
}

\author{
J-F, M. Dorville* and N. Zahibo*
}

Laboratory of Geoscience (LaRGe), University of Antilles Guyane, Guadeloupe (F.W.I.)

\begin{abstract}
A swell produced by the Hurricane Omar touched the west Guadeloupean coasts during the period of the $15^{\text {th }}$ to the $17^{\text {th }}$ in October 2008. The waves of this swell hit different islands of the Greater and Lesser Antilles arc. The cost of the destruction of this swell was evaluated at \$ 46 million. On the island of Basse-Terre in the archipelago of Guadeloupe all the exposed zone, the quiet west coast was impacted by waves of observed height around 2.5 to $3 \mathrm{~m}$. The totality of this zone was modified by the effects of the waves, on more $100 \mathrm{~m}$ in the land. By a complete observation of the Hurricane Omar, the causes and the consequences of the waves are described. The propagation of the waves on the coast and in the land of the west part of the island of Basse-Terre is particularly described. The compilation of the different testimonies, the observations on several spots of the coast and the buoys measurements in the Caribbean Sea allow to give the synoptic of the event and to qualify the consequences of the impact of the waves. To give more accurate values of the characteristics of the waves, some numerical simulations of the wave propagation were made with SWAN under realistic conditions and near the coast. The numerical simulation and the measurements are in accordance with the observations and the different testimonies, waves of $2.5-3 \mathrm{~m}$ height and $12 \mathrm{~s}$ of peak period. To conclude, some indications for the future are given to help to protect the coastal population.
\end{abstract}

Keywords: Storm surge, hurricane omar, lesser antilles, wave observation, wind.

\section{INTRODUCTION}

In the night of Wednesday the $15^{\text {th }}$ and Thursday the $16^{\text {th }}$ in October 2008, a strong cyclonic swell hit the Caribbean coast of Guadeloupe Island. An alert of orange level had been given by the prefectoral office for the coastal zones. This alert corresponded to a level of 3 out of 5 . The Forecasting of the height of the waves went from 3 to $6 \mathrm{~m}$ for the most extreme cases. The level of orange alert implied an increased vigilance, but not the obligation of closed the offices and buildings in the zones concerned. The waves arrived initially with a southwest component before going up gradually, and finishing at the end of the event with a very northern component in the day of Friday October $17^{\text {th }}$.

In the archipelago of Guadeloupe (Fig. 1), the zones mostly hit by the waves were the directly exposed coastal zones: the western-south of Marie-Galante; the beaches of the western-south of Terre-de-Haut and the leeward coast shores of Terre-de-Bas, in Les Saintes; the whole west coast of the island of Basse-Terre, going from the city of BasseTerre in the south to Ste. Rose in the north, going through Baillif, Vieux-Habitants, Bouillante, Pointe-Noire and Deshaies.

The effects of the waves were felt on such a broad zone because of the change of directions of the swell. All the testimonies referred to large-sized waves along the coast, particularly between the city of Deshaies and Bouillante. They talked about waves of $3 \mathrm{~m}$ of height which represented 6 to 8 times larger than the ones on these zones during wind squall.

\footnotetext{
*Address correspondence to these authors at the Laboratory of Geo Science (LaRGe), University of Antilles Guyane, Guadeloupe (F.W.I.);

E-mail: jforvil@univ-ag.fr; narcisse.zahibo@univ-ag.fr
}

The protection of the coastal zone for waves of this dimension was currently and completely controlled. For example, on all this zone, dams were gradually set up after each large cyclonic swell like: Dean (August 2007); Ivan (September 2004); Lenny (November 1999) or George (September 1998). The average heights of the dams on this coast are around 2.5 to $3 \mathrm{~m}$ above the sea surface. The dams were constructed to protect the different fishing ports, the coastal roads and the buildings. All the dams resisted in the zone of the impact of the swell. But the most part of the waves went over each of them during the second part of the night from the $15^{\text {th }}$ to the $16^{\text {th }}$ and the first part of the morning. The water of the waves which went over the dams caused floods on all the zones.

When the swell of the Hurricane Omar arrived, the tide was rising. The variation of the sea level during the first 12 hours was in the rate of $40 \mathrm{~cm}$ for the islands of Guadeloupe and Martinique according to the estimations of the SHOM (Hydrographic and Oceanographic Service of the French Marine). This variation can certainly explain how the sea water went over the dams of $3 \mathrm{~m}$ high while the waves were smaller.

It is not possible to estimate the real height of waves on the Caribbean coast of Guadeloupe. Indeed no device of measurement of swell on this coast was available. The only measuring apparatus of sea level variation was the tide recorder of Deshaies, monitored by the BRGM (Office of Geological and Mining Research).

In this article the event from the $15^{\text {th }}$ to the $16^{\text {th }}$ is described firstly by a historical review of the phenomenon. In the second part the consequences of the swell impact are analyzed with the testimonies of the inhabitant of the west 


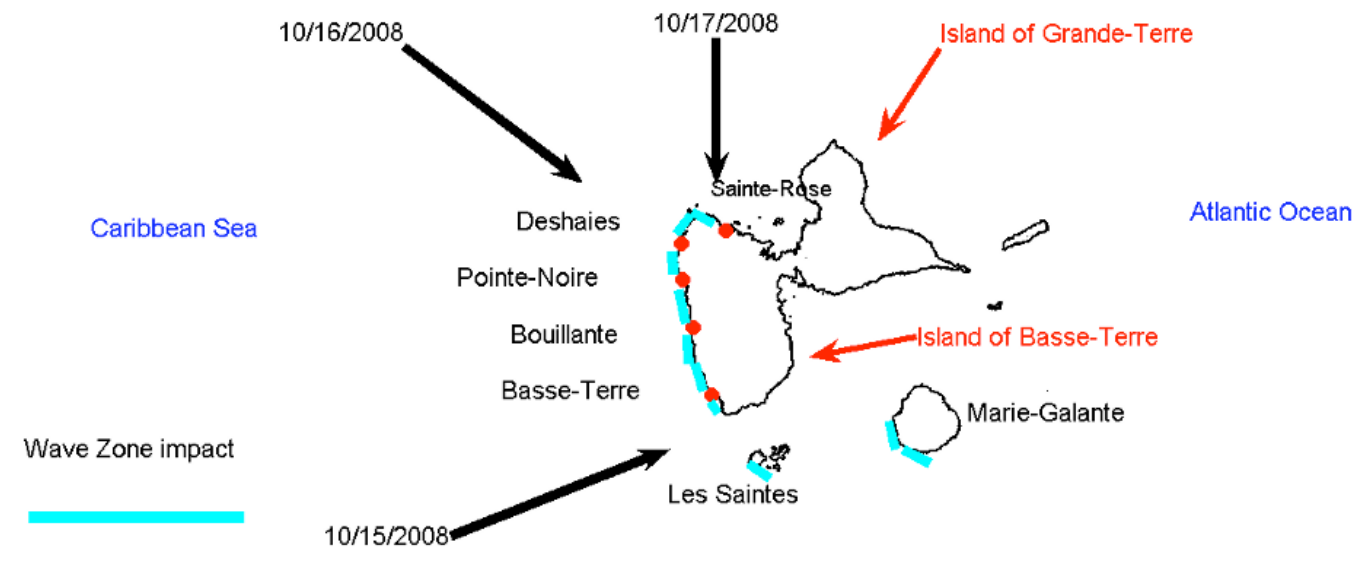

swell direction

The Saint Channel

Fig. (1). Map of the archipelago of Guadeloupe.

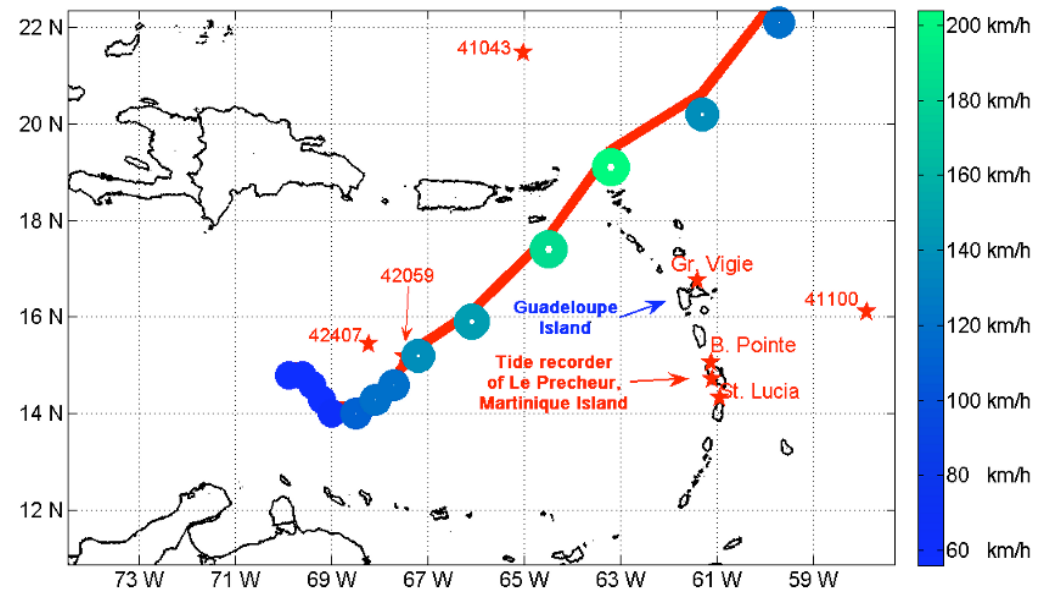

Fig. (2). Trajectory of the Hurricane Omar.

coast of Basse-Terre Island and some observations spots. In the third part, the waves induced by Hurricane Omar are characterized with the different measurements in the Caribbean Sea, and on the coast, in the port of Deshaies. To finish a numerical simulation of wave (SWAN [1]) is used to compute the propagation of the waves on the west coast of the island of Basse-Terre.

\section{HURRICANE OMAR}

In the last 20 years, there were a large number of hurricanes in the Caribbean Sea [2-6], more than 230 atmospheric perturbations which crossed the Caribbean Sea can be counted. On this, 166 were hurricanes and 68 were tropical waves. The hurricanes which reached the high level of the scale, more than category 3 were more than 100, which represents an estimation of 5 perturbations per year really dangerous for this side of the Guadeloupean coast. In this same period 8 hurricanes swell were counted on this coast, so one every two years. The frequency of the passage of strong hurricanes on the Caribbean Sea and the frequency of the swell impact on this zone indicated that it needs to be under close observation.

The Hurricane Omar was a tropical atmospheric wave, formed near the Trinidad coasts. It went up before reaching sufficiently hot water in the center of the Caribbean Sea [7]. Omar was a hurricane of category 4 on Saffire Simpson Hurricane Wind Scale. The strongest winds were estimated at $204 \mathrm{~km} / \mathrm{h}$ with gusts of $250 \mathrm{~km} / \mathrm{h}$. It remained only a very short time in category 4 before going down to a storm in a first time. In a second time, it became again a hurricane of category 1 and finished to die out on the Atlantic Ocean the $17^{\text {th }}$. During its working life, Hurricane Omar was influenced by two large anticyclones which modified its trajectory and by another depression located on the Atlantic which pumped it towards north. Due to these influences, the trajectory of the Hurricane Omar first of all was in the shape of circle arc. It turned around the center of the Caribbean Sea, before having a less common component with a northeast direction in the Caribbean Sea. It went out of the Caribbean Sea by the Anageda passage, between the Virgin Islands and Anguilla Island in the north part of the Lesser Antilles Arc. 


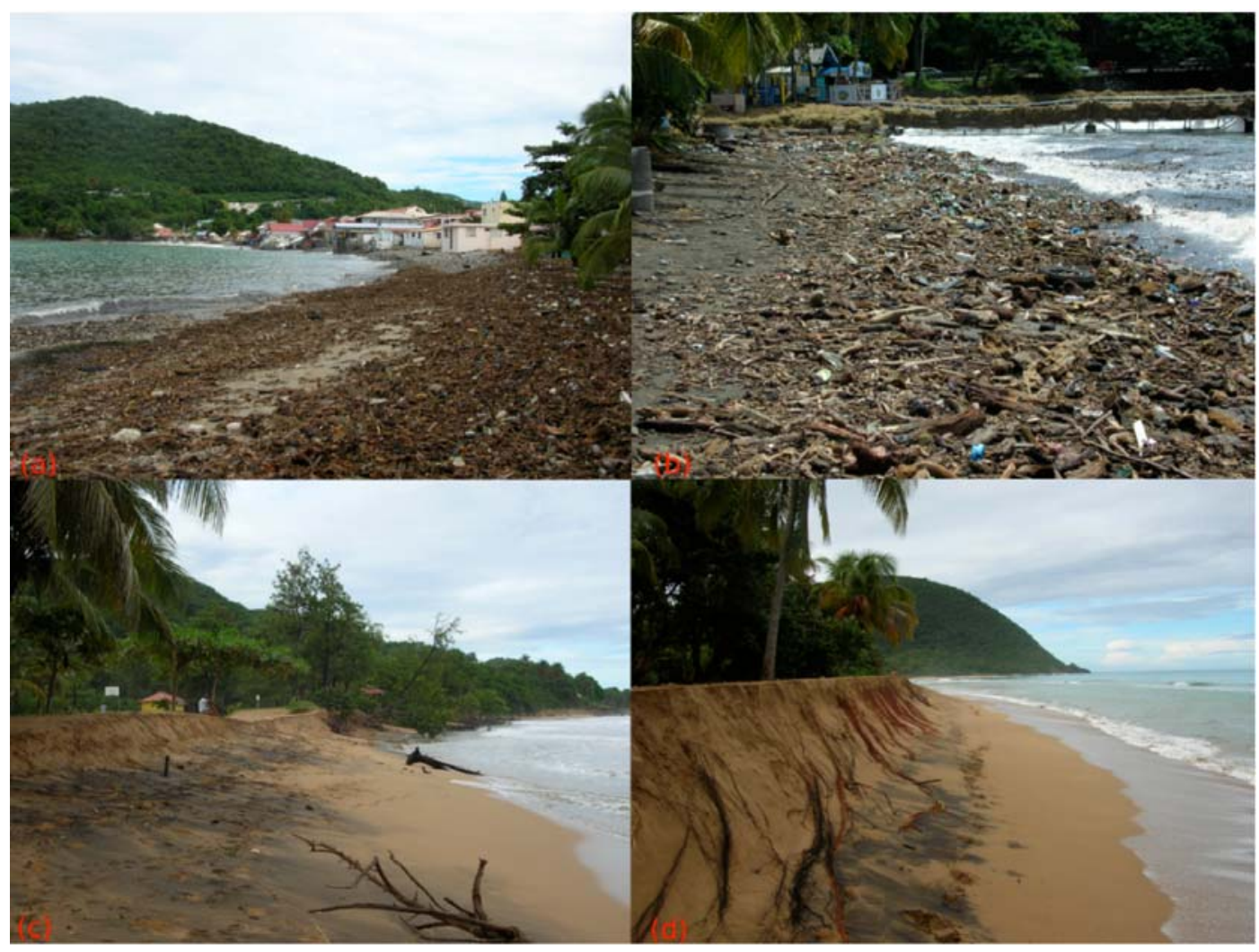

Fig. (3). Waves effects on the beaches (a)Center of Deshaies; (b)Malendure, Bouillante; (c)La Perle, Deshaies; (d)Grande-Anse, Deshaies.

The damages caused by the passage of the Hurricane Omar on the islands or near the islands of the West-Indian Arc were estimated at 46 million dollars, and it caused the death of two persons. The direct effects were on PuertoRico, the Virgins Islands, St Martin, St Barth, Saba. In its trajectory, Hurricane Omar anyway avoided the majority of the lands emerged. The Hurricane Omar caused thereafter large damage especially related to these waves on the islands of the north of the Lesser Antilles, the Virgins Islands, St. Martin etc. But the waves of the Hurricane Omar were felt on the whole coasts of the Lesser Antilles arc. The fact that it was near explains the effects in spite of the average wind forces. Hurricane Omar remained in the high categories of cyclone only during a short time between 12 and 24 hours.

The trajectory of the Hurricane Omar going from the southwest to the northeast in the Caribbean Sea is not frequent. In the last 20 years it is the single hurricane which got this direction. In the same period the second perturbation which took this direction is the tropical storm Odette in 2003 [4]. This trajectory explains the variations of the direction of the swell observed. The consequences of the oblique trajectory regarding the Lesser Antilles arc were the variation of the distances between the Hurricane Omar and the various points on the Basse-Terre Island's coasts and the shifted arrival of the waves.

\section{OBSERVATIONS OF THE EFFECTS OF THE WAVES}

Witnesses living around the port of Deshaies were woken up by the sound of the sea around $12 \mathrm{pm}$ at local time the $15^{\text {th }}$. Some of them went to inspect the port. They observed the presence of abnormal waves. On the rest of the west coast of the Basse-Terre Island, the residents indicated the beginning of the big waves between $12 \mathrm{pm}$ and $4 \mathrm{am}$. The majority of the inhabitants were sleeping at this time. They were woken up by the presence of water in their houses or for the luckiest ones by the sound of the waves. They all indicated the end of the large waves after $1 \mathrm{pm}$ at local time the $16^{\text {th }}$.

The testimonies of the residents and the fishermen located on the west side of the Basse-Terre Island were compared. Most of them gave the same sequences of the event, a rising of the wave during the night, a general sea elevation and the flooding caused by waves which jumped the dams in the protected zone or by breaking waves for the other. The most part of the event was during the night, the evaluations of the height wave by the witnesses need to be considered carefully. After the passage of the largest waves, the witnesses of the zone protected by dams indicated the difficulty for the water to flow out in sea. People located near the shore line indicated the violence of the event, the presence of rocks in the waves and the difficulty to evacuate and to keep safe any object during the event. But they certified than Hurricane Omar waves were less powerful than Hurricane Lenny or Hurricane George ones.

In the days after the passage of the higher waves, the totality of the west coast of the island of Basse-Terre was inspected. The sea stayed very rough. Some pictures of the different zones (Fig. 3) were taken. The whole of the beaches of weak slope were covered by water. Many remains are visible on the photograph of the center of Deshaies (Fig. 3a) and the photograph of Malendure at Bouillante (Fig. 3b). They were moved and deposited by the waves. The size of the objects is a good indicator of the waves force. Few bulky 


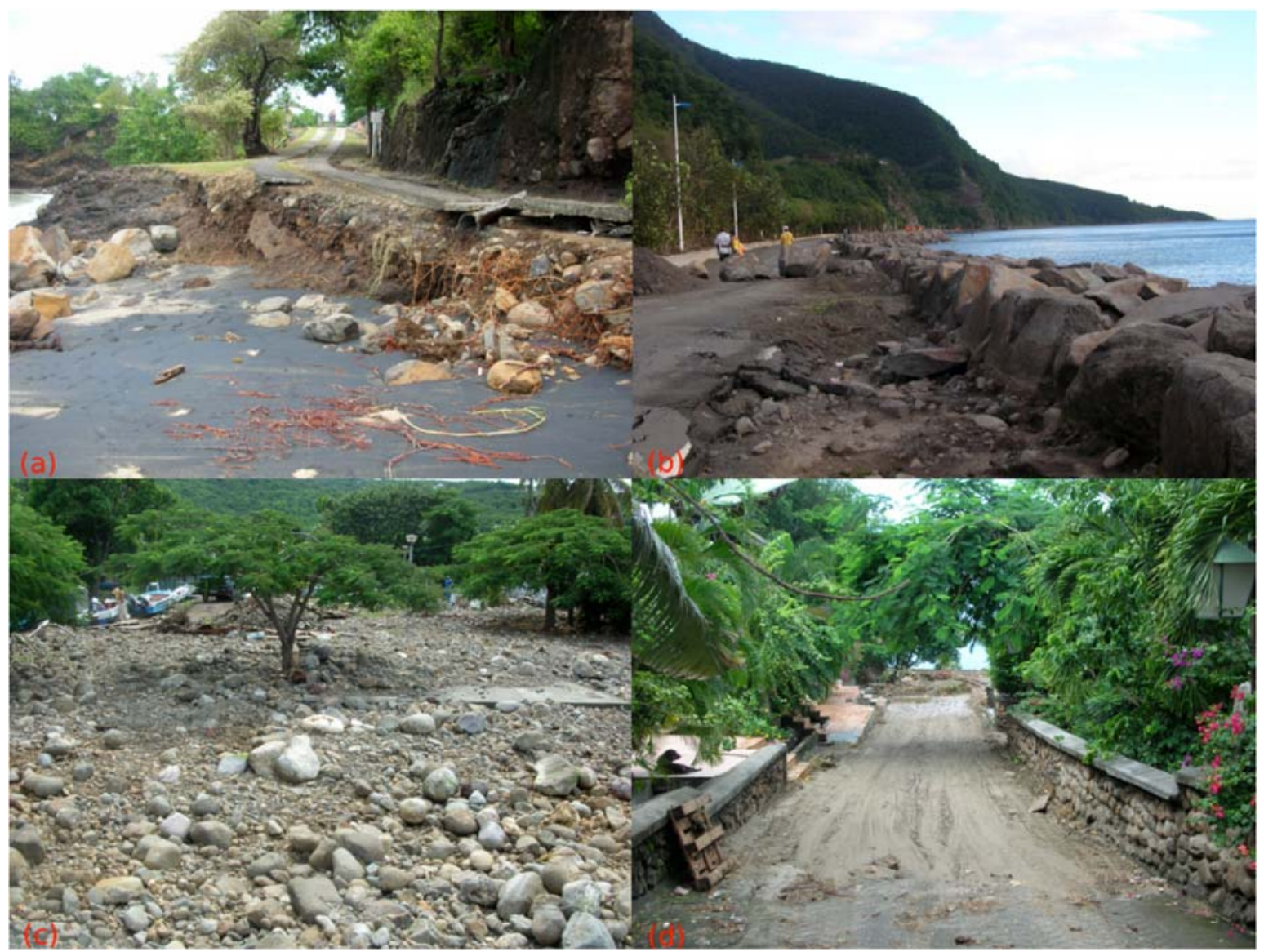

Fig. (4). Waves effect on the shore (a)Le Roux, Pointe-Noire; (b)Rivière-Sens, Basse-Terre; (c)Ferry, Deshaies; (d)Petite-Anse, PointeNoire.

objects were moved during that period, it remains relatively weak compared to other hurricanes as Lenny in 1999, which moved rocks of almost $2 \mathrm{~m}$ in diameter. On the beaches with the strongest slopes, like those of La Perle and Grande-Anse, Deshaies, the waves had a more impressive effect by moving strong heaps of sand (Fig. 3c). On the beach of GrandeAnse, Deshaies, on more than $500 \mathrm{~m}$, the waves moved a volume of more than $1.8 \mathrm{~m}$ on $5 \mathrm{~m}$ of sand compared by the precedent inspection. That is to say a volume of more than $4500 \mathrm{~m}^{3}$ was moved during the 24 hours of impact of the waves (Fig. 3d). These sands are found in the bay bordering the beaches and contribute to the modification of bathymetry near the beaches. This displacement makes the lines of shore go up. In the case of Grande-Anse, this line was measured during more than two weeks $1 \mathrm{~m}$ higher than normal conditions.

The strong rise of the general sea level caused the destruction of the small-sized constructions like the concrete road on the beaches Le Roux at Pointe-Noire (Fig. 4a), and the rise of the sea level cut down in depth the earthy zones. On the littoral road between Vieux-Fort and Basse-Terre (Fig. 4b) the dam held perfectly. But not the road behind which was cut down. The sea water elevation made it possible for the waves to flow over the dams and to flood the zone. Rocks and other elements moved by the waves finished the work of destruction (Fig. 4b). But in the places not protected by the dams, such as the northern zone of Ferry, Deshaies, many rocks settled on the pebble beach. The size of the rocks was not exceeding $50 \mathrm{~cm}$ in diameter, which indicates waves of average force (Fig. 4c). The rise of sea water was particularly significant, since in Petite-Anse, Pointe-Noire (Fig. 4d), traces of sands after the passage of the waves, indicate water which covered more than $100 \mathrm{~m}$ in the lands, rose more than $3 \mathrm{~m}$ over the normal sea surface.

\section{OBSERVATIONS OF THE SWELL OF OMAR}

The value of the height of water is taken every $15 \mathrm{sec}-$ onds in the port of Deshaies, $\left(16^{\circ} 18^{\prime} 18^{\prime \prime} \mathrm{N}, 61^{\circ} 47^{\prime} 44^{\prime \prime} \mathrm{W}\right.$ position measured by Trimbel GeoTX), with a ultrasound tide recorder (FALMOUTH SCIENTIFIC model EOPM2). The frequency of measurement is too large to observe the waves induced by wind. Wind wave and swell wave are defined with wave period lesser than 30 s [8, 9]. The large time of frequency of measurement can not help to determine the wave period of the wind and swell wave. The variation of the height of water in the port is the principal information of this tide recorder, presented in Fig. (5), according to a time of reference chosen at $4 \mathrm{~h}$ in UTC (Universal Time Clock). The time of reference was chosen with the testimonies of Deshaies inhabitants (traced in red on the Fig. 5). In the periods of normal conditions, variations of the height of water in the port of Deshaies are about $5 \mathrm{~cm}$, it is a very quiet zone, recently protected by a dam of $3 \mathrm{~m}$ height. This limit is used to determine the start of the perturbation in the port of Deshaies (traced in green on the Fig. 5) at $3 \mathrm{pm}$ the $15^{\text {th }}$ (19h in UTC) that is to say 9 hours before the time reference. From the 


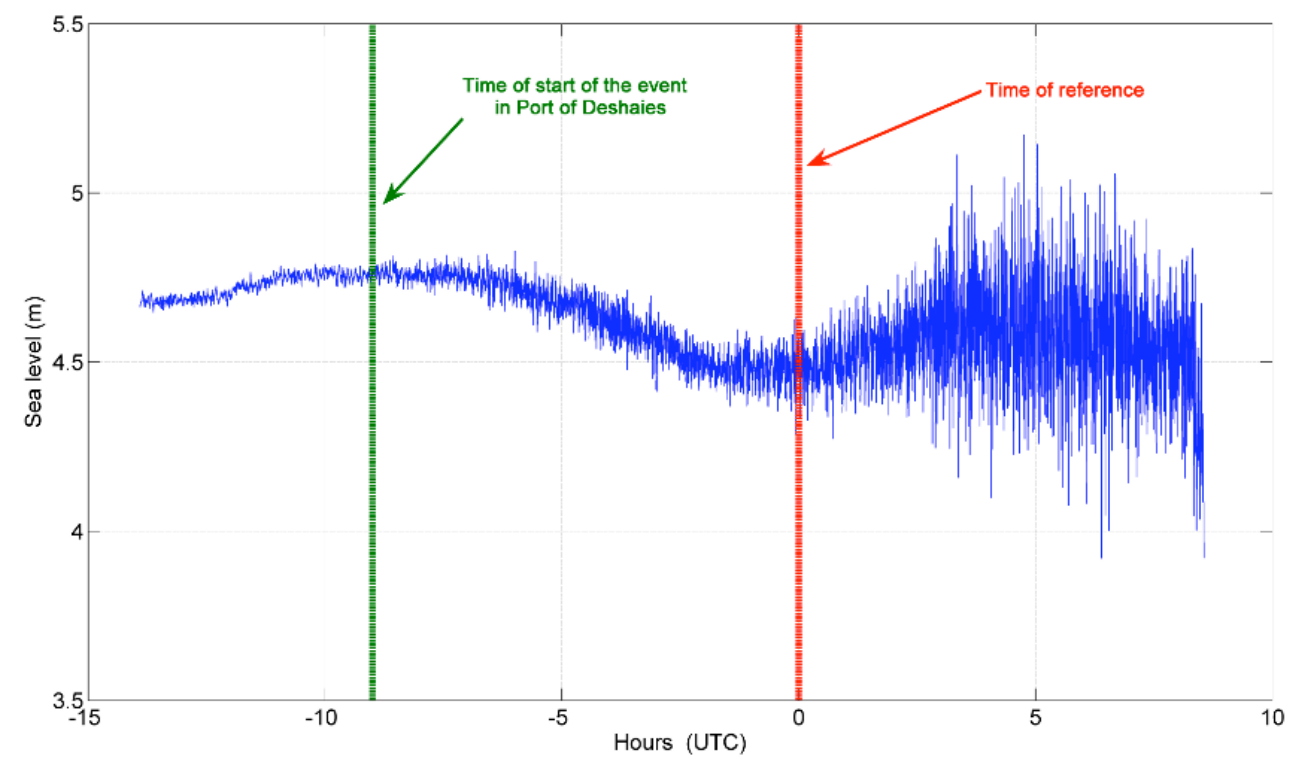

Fig. (5). Measurement of the tide recorder of Deshaies.

Table 1. Position of the Wave Buoys

\begin{tabular}{|c|c|c|c|}
\hline Buoy & Geographic Coordinates & Location & Monitored by \\
\hline Grande-Vigie & $16^{\circ} 31^{\prime} 59^{\prime \prime} \mathrm{N}, 61^{\circ} 24^{\prime} 14^{\prime \prime} \mathrm{W}$ & North part of the island of Grande-Terre & $\begin{array}{c}\text { Météo France (French Weather } \\
\text { Agency) }\end{array}$ \\
\hline Basse-Pointe & $14^{\circ} 53^{\prime} 38^{\prime \prime} \mathrm{N}, 61^{\circ} 6^{\prime} 47^{\prime \prime} \mathrm{W}$ & North part of Martinique & $\begin{array}{c}\text { Météo France (French Weather } \\
\text { Agency) }\end{array}$ \\
\hline Sainte-Lucie & $14^{\circ} 10^{\prime} 41^{\prime \prime} \mathrm{N}, 60^{\circ} 56^{\prime} 13^{\prime \prime} \mathrm{W}$ & North part of St Lucia & $\begin{array}{c}\text { Météo France (French Weather } \\
\text { Agency) }\end{array}$ \\
\hline Station 41140 & $17^{\circ} 46^{\prime} 7^{\prime \prime} \mathrm{N}, 64^{\circ} 43^{\prime} 24^{\prime \prime} \mathrm{W}$ & South of St Croix, Virgins Islands & NOAA \\
\hline Station 42059 & $15^{\circ} 0 \prime 20^{\prime \prime} \mathrm{N} 67^{\circ} 29^{\prime} 44^{\prime \prime} \mathrm{W}$ & East of the Caribbean Sea & NOAA \\
\hline
\end{tabular}

starting of the perturbation in the port of Deshaies, the variations grow and reach values higher than $60 \mathrm{~cm}$, 15 times more. The tide recorder stayed available between 8 and 10 hours after the beginning of the higher wave in the port of Deshaies. After this time the tide recorder broke down.

The variations of the local atmospheric pressure measured by the tide recorder device of the port of Deshaies, indicated a presence of a weak depression. The pressures decreased in the first 5 hours, to reach a value of $1010 \mathrm{hPa}$, then to go up above the average pressure of $1015 \mathrm{hPa}$. The increase indicates the end of the influence of the depression. The weak depression does not indicate a significant risk of abnormal sea elevation, of about $3 \mathrm{~cm}$ according to the principle of hydrostatics.

The tide recorder of Le Prêcheur in Martinique (Fig. 2), controlled by The General Council of Martinique $\left(14^{\circ} 49^{\prime} 13^{\prime \prime} \mathrm{N} 61^{\circ} 13^{\prime} 42^{\prime \prime} \mathrm{W}\right)$ enables to observe the variations of the sea level in the Caribbean Sea, near the Guadeloupe Island. The variations of a point of measurement to the other ranged from one millimeter to ten centimeters. Another measurement of sea level using buoys DART 42407 (Deep Ocean Assessment and Reporting of Tsunamis [10]) in the middle of the Caribbean Sea, (15 $\left.15^{\prime} 36^{\prime \prime N} 68^{\circ} 14^{\prime} 28^{\prime \prime W}\right)$ permits also to observe a discontinuity in the variations of the level of the sea surface. The height of the sea surface is slightly different than the estimated values during 3 tide cycles. These variations can indicate the coming then the going away of the disturbance of the measuring buoy.

The measurements of waves height observed by the wave buoys of Grande-Vigie, Basse-Pointe, Sainte-Lucia, the Station 41140 and the station 42059 (Table 1 \& Fig. 2) indicate that the significant heights $(\mathrm{Hs})$ of the waves which hit the coast of Guadeloupe were higher than $2.5 \mathrm{~m}$ (Fig. 6) and with a peak period of waves (Tp) of about 10 to 12 seconds (Fig. 7). The peak period (Tp) and the significant height (Hs) of the waves were given by the density spectrum energy during the procedure of measurement of waves of the buoys. The peak period indicating the values of frequency of the maximum energy and the significant height equal to $\mathrm{Hs}=4 *\left(\mathrm{~m}_{0}\right)^{1 / 2}$ $[8,9], \mathrm{m}_{0}$ is zero spectrum moment.

The waves that arrived on the buoy of Grande-Vigie were similar to the ones of the Caribbean coasts of Guadeloupe Island. It has they have only been propagated on longer distances, about $40 \mathrm{~km}$. It is thus considered that they underwent an additional attenuation. 


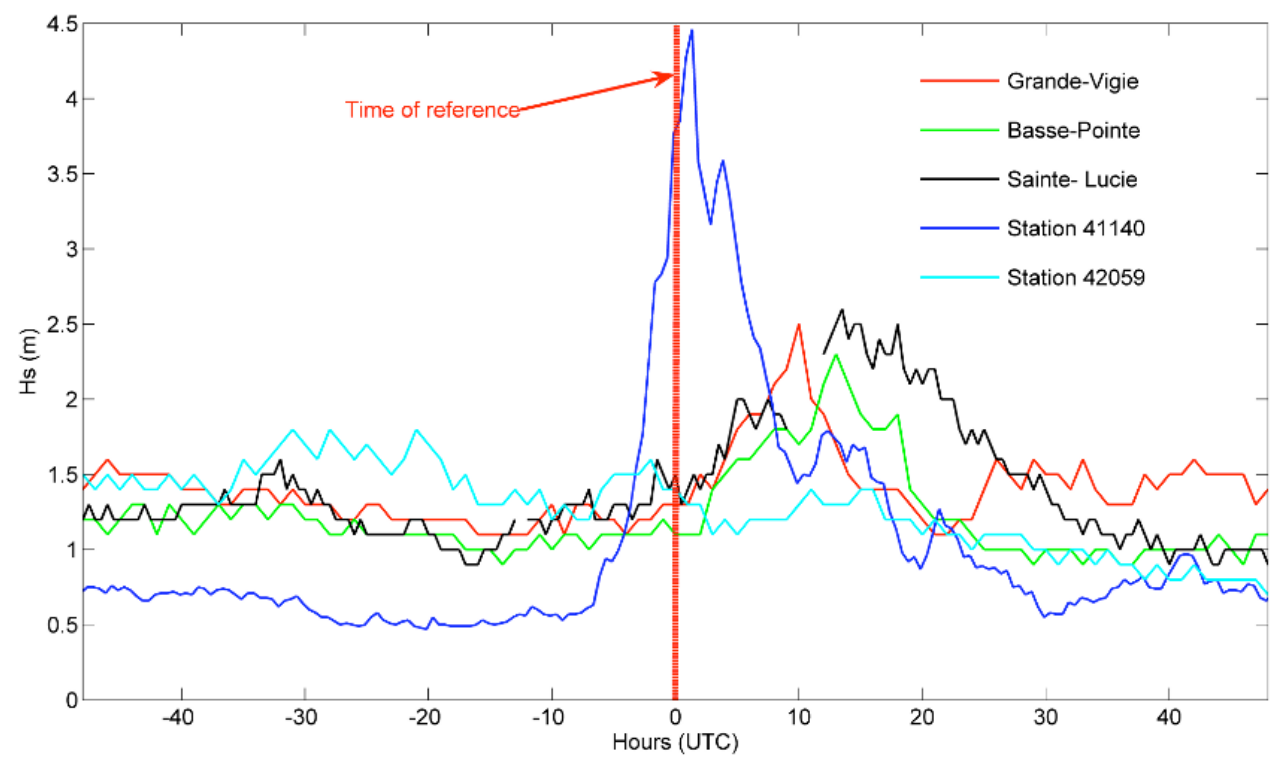

Fig. (6). Measurement of the swell significant height.

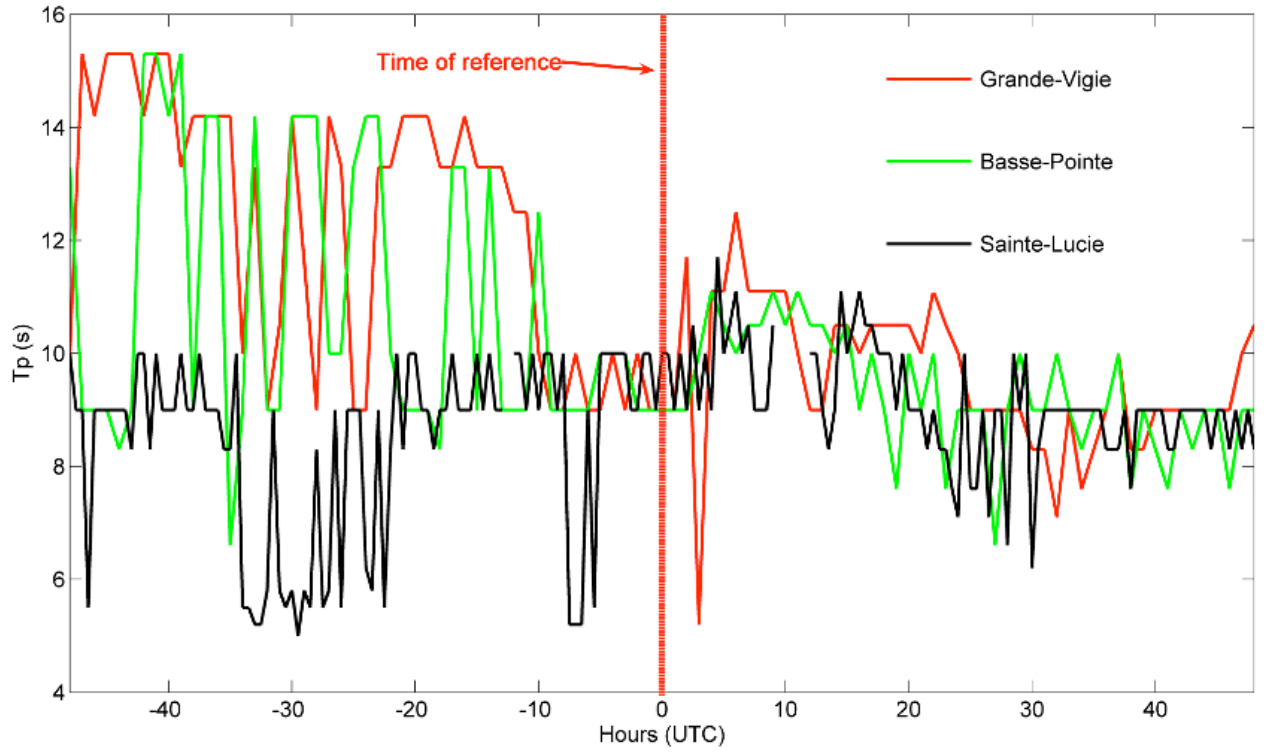

Fig. (7). Measurement of the swell period of the peak.

The condition of wind in the north of Guadeloupe Island was quiet. The values of the wind speed were near $10 \mathrm{~m} . \mathrm{s}^{-1}$ with a short period of intensification. The effects of the wind on the waves of this height were nearly negligible [8].

The directions of waves for the three buoys of the French Weather Agency (Fig. 7) indicate their origin (Northwest after time zero during 12 hours). During this period no other important perturbation was near this zone. That indication helped to conclude that the waves which impacted the west coast of the French West Indies came really from the swell of the Hurricane Omar. Besides, the waves of the Hurricane Omar which impacted the coast of Guadeloupe were lower than $3 \mathrm{~m}$ of height and $12 \mathrm{~s}$ of peak period.

The distances between the Hurricane Omar and the points of measurement were compared (Fig. 8), it is noted that the beginning of the events observed occurred systematically when the hurricane was in its nearest position to the point (Figs. $2 \& 8$ ). This is valid for the "tide recorder" of port of Deshaies, the buoy of Grande-Vigie, the tide recorder of Le Prêcheur and the buoy of Basse-Pointe. On the two last spots the event started earlier than the two others.

\section{NUMERICAL SIMULATION OF THE PROPAGA- TION OF THE WAVES}

During the period of the impact of the swell of the Hurricane Omar no devices were available to make accurate measurements on waves. But the evaluation of the characteristics (Hs, Tp, and direction) of the waves near the coast is necessary to evaluate their risk level. Numerical simulations of the waves propagation were made for the period of the greater impact of the Hurricane Omar swell near the west coast of Guadeloupe. By taking into account of the data of the Grande-Vigie buoy, the values of the period went from $4 \mathrm{am}$ to $8 \mathrm{pm}$ the $16^{\text {th }}$ were chosen to the boundary conditions of the numerical simulation. The Model used for this simula- 


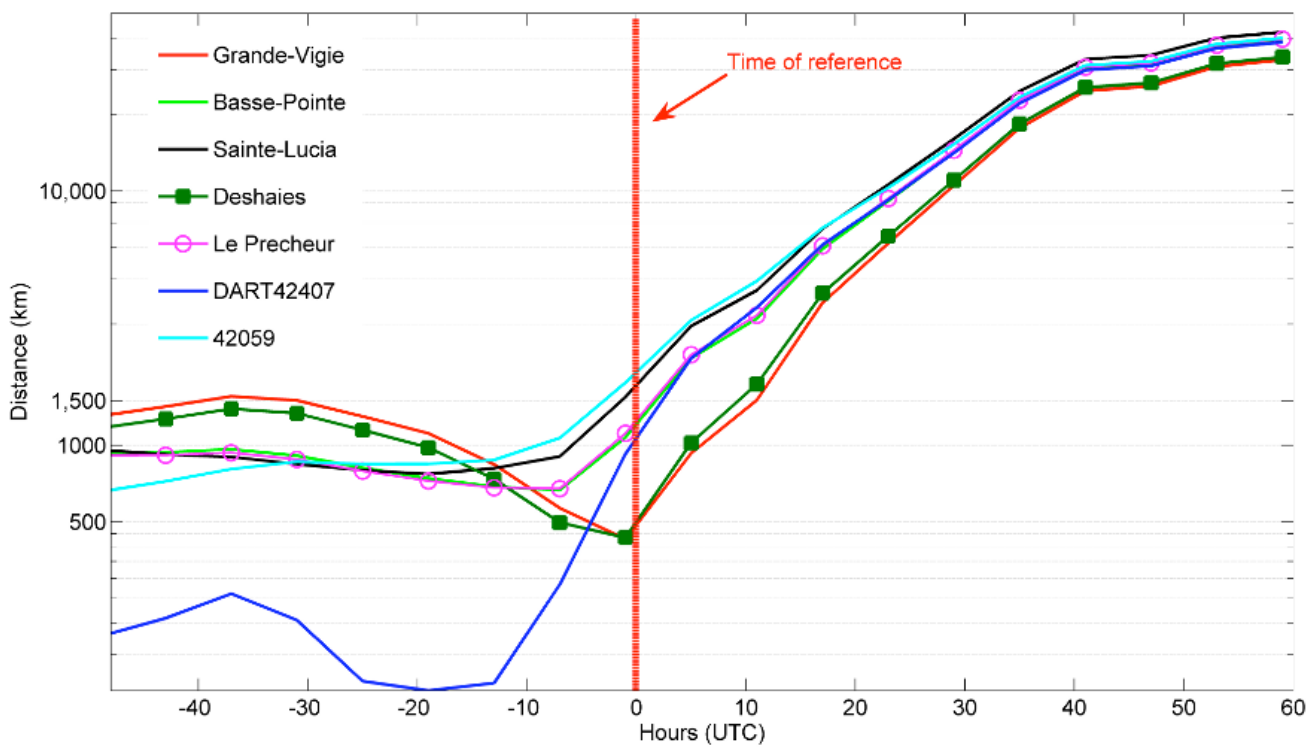

Fig. (8). Evolution of the distance between the Hurricane Omar and several point of measurement.

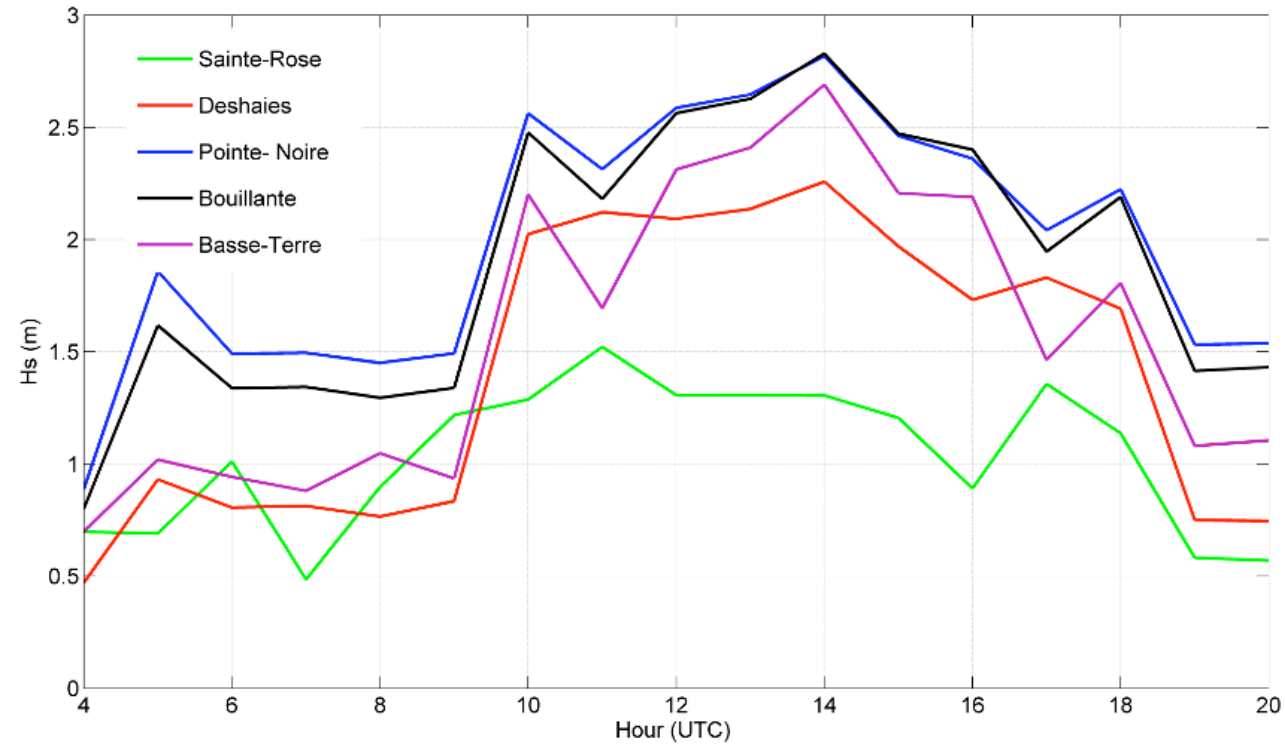

Fig. (9). Significant height of waves obtained by numerical simulation (SWAN[1]) of waves propagation on several points of the exposed coast.

tion during the period is SWAN [1]. It is a third generation model of wave propagation which was used on a computational mesh of 30 arc seconds of precision given by GEBCO [11]. The spectral model of the initialization was a JONSWAP, with a friction model applied. The wind imposed in the model was given by the wind map of initial value of the GFS Model [12]. Some simulations using a homogenous wind with a value of $10 \mathrm{~m} . \mathrm{s}^{-1}$ referred to the testimonies. It assumed that the wind has the same direction as the waves. The two results are very close less than 0.1 of relative difference. The homogeneous cases do not take into account a lesser wind speed in the beginning of the largest waves.

On the coast, values of significant height around $2.5 \mathrm{~m}$ (Fig. $9 \& 10$ ) and peak period of 12 s were obtained by the numerical simulation for the spots most exposed by the waves. The numerical estimations of the height of the waves
(Fig. 9) during the greatest impact period are between 1 to $1.6 \mathrm{~m}$ for the city of Ste. Rose, 1.8 to $2.2 \mathrm{~m}$ for the port of Deshaies, 2 to $2.8 \mathrm{~m}$ for the city of Pointe-Noire, 1.6 to $2.8 \mathrm{~m}$ for the bay of Bouillante and 1.5 to $2.6 \mathrm{~m}$ for the city of Basse-Terre (Fig. 1). The estimation is lower than the reference of the testimonies but the few frequencies of wave of big height on this coast give difficulties to have a good estimation on the height of the waves. Most part of the visual estimation of the height of the waves was during the night, it could explain the difference. The values given by the simulation are in accordance with the buoys values. The period of greatest impact of the waves was between $10 \mathrm{~h}$ and $16 \mathrm{~h}$ at UTC, or 4am to $12 \mathrm{am}$ at the local time, according to the numerical simulation. At $4 \mathrm{~h}$ (UTC) the height of waves was already important, around $1 \mathrm{~m}$ so 3 to 4 times greater than the normal condition. The difference of the testimonies at the 


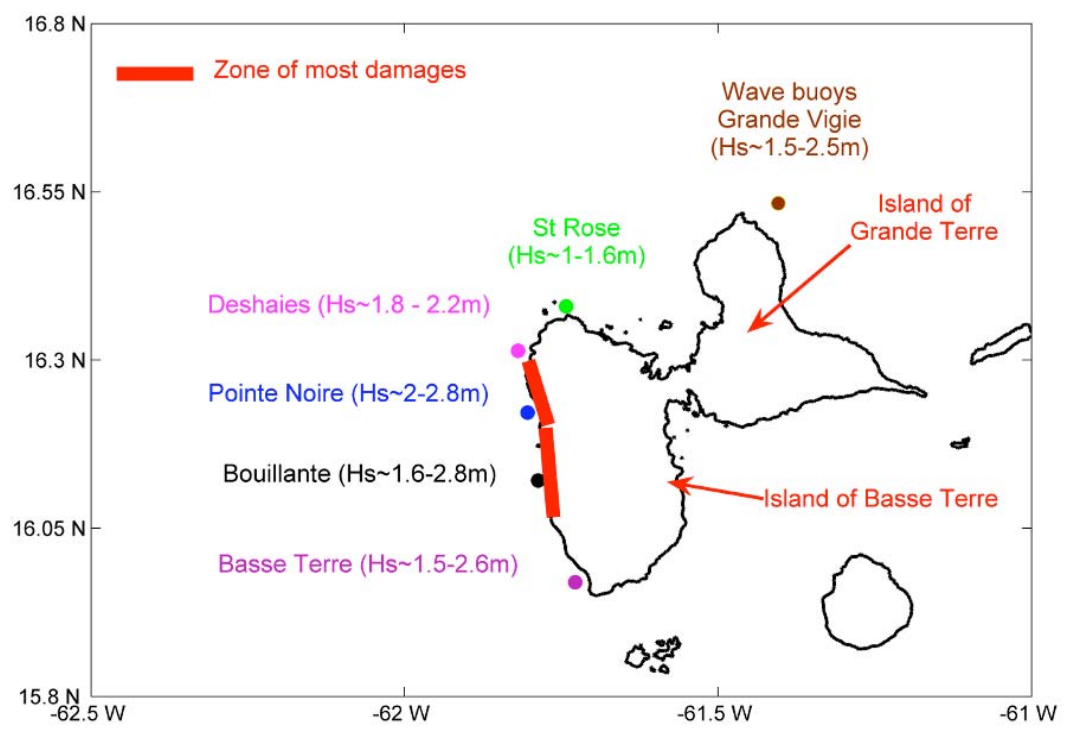

Fig. (10). Cartography of the numerical simulation results.

Table 2. Compilation of the Simulation and Observation During the Greatest Impact of the Waves

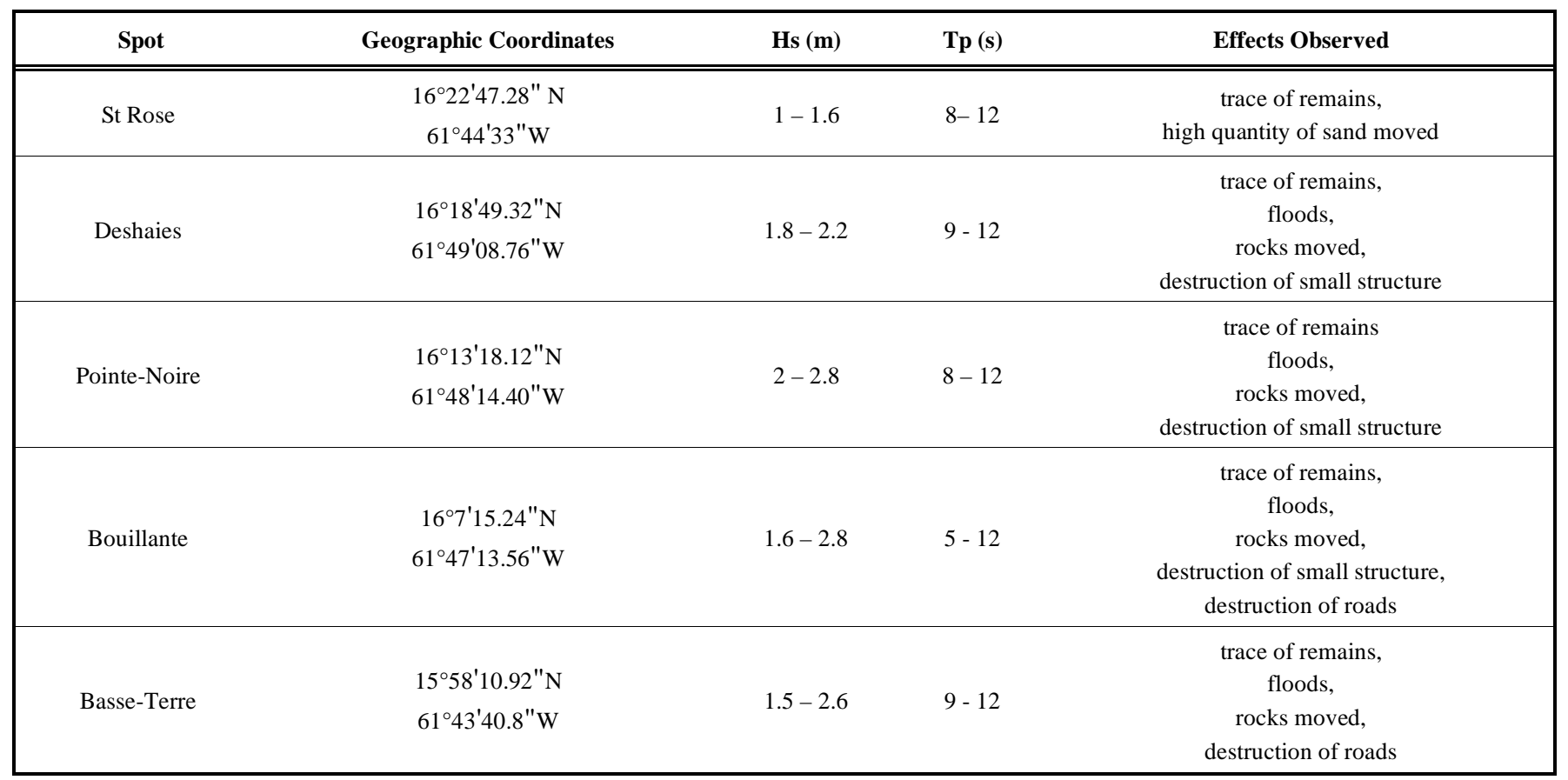

beginning of the big waves could be explained by the presence of these waves early in the night.

\section{DISCUSSION \& CONCLUSION}

On the 230 atmospheric perturbations which crossed the Caribbean Sea in the last 20 years, the Hurricane Omar was the only one to have this particular trajectory (Fig. 2), from the west to the East. The different observations helped to conclude that the cyclonic swell did come from the Hurricane Omar. The effects of the waves started when the hurricane was very close to Guadeloupe coast $(<500 \mathrm{~km})$, its sustained winds were between 140 and $190 \mathrm{~km} \cdot \mathrm{h}^{-1}$.

The effects of the waves were visible on more than $100 \mathrm{~m}$ in the land and $3 \mathrm{~m}$ above the normal sea surface level. The damages were observed on all the west coast of the BasseTerre Island. Behind the dams, the water of the waves which jumped over the dams caused floods and destroyed the majority of the roads. Strong quantities of sand were moved during the passage of the waves on different sand beaches. The sand displacement caused the modification of the bathymetry near the coast and rose the shore line during more than two weeks. The displacement of rock of average size $(50 \mathrm{~cm}$ of diameter) caused by the waves agitation induced damages and blocked the passage to the pebbles beaches.

The size of the waves ranged from about $2.5 \mathrm{~m}$ to $3 \mathrm{~m}$, with peak periods lower than $12 \mathrm{~s}$ if the data of buoy (Grande-Vigie) located near the Guadeloupe Island is fol- 
lowed. If the values given by the numerical simulations (Table 2 \& Fig. 10) are taken into account, the waves were between 2.2 and $2.8 \mathrm{~m}$ of height and $12 \mathrm{~s}$ of period on the west coast of Basse-Terre Island. These values are in line with the observations and the testimonies. The estimated value (tide recorder variations) of the variation of the sea level in the port of Deshaies was in the first time of the event 9 hours before the time reference and 8 hours after the sea level variation more than $0.6 \mathrm{~m}$. This value of the sea level variation was 15 times more than the normal condition in the particular case of the port of Deshaies.

The numerical simulation proposed in the case of hindcasting is in accordance with the measurements and the observations. It needs to be performed to be used in prevention. The comparison with the testimonies indicate a under evaluation of the numerical model, but can be explained by the difficulty to evaluate the height of a wave during the night, by people who are not used of seeing waves of this size.

The effects of the hurricanes were especially due to the presence of waves on the west coast of the Basse-Terre Island 6 to 8 times larger than the normal conditions. No loss of human beings was recorded but a great loss of material of several million Euros. In the zone in spite of the presence of dams, the rise of the sea level still represents a real danger. The dams are useful for the protection of powerful waves, but are slightly adapted in the case of flood. The alerts in this case must be more systematically and more strictly respected by the population. In fact, any swell higher than $2 \mathrm{~m}$ on the Caribbean coast of Guadeloupe must be regarded as a major risk.

A real system of protection composed by measurement and prevision system needs to be created for the west coast of the Basse-Terre Island which could be a major attracted zone for tourism.

\section{ACKNOWLEDGEMENTS}

The authors are grateful to the French Weather Agency (Météo France) for the data they sent very quickly, specifically Mr Mazurie and Mr Berthelot. We are also grateful to Patrick Siarras and Dr. Pascal Poullet, for the technical support on the super computer of the C3I-UAG and to Dr. Jack
Molinié for his valuable advices. We are very thankful to Dr. Ira Didenkulova for her helpful suggestions to improve the quality of the manuscript. Thanks are also due to NOAA and GEBCO for the data downloaded from NOAA website http://www.nhc.noaa.gov/ and from GEBCO world map, http://www.gebco.net/.

This research work has been supported by the grant INTERREG IIIB Espace Caraïbes.

\section{REFERENCES}

[1] Booij N, Ris RC, Holthuijsen LH. A third-generation wave model for coastal regions, Part I, Model description and validation. J Geophys Res 1999; 104; C4: 7649-66.

[2] Saffache P, Marc JV, Cospar O. Les cyclones en Martinique : quatre siècles cataclysmiques (éléments pour une prise de conscience de la vulnérabilité de l'île de la Martinique). Ibis Rouge Editions: Paris, France 2001; p. 197.

[3] Saffache P, Marc JV, Huyghues-Belrose V. Les cyclones en Guadeloupe: quatre siècles cataclysmiques (éléments pour une prise de conscience de la vulnérabilité de l'archipel guadeloupéen). Ibis Rouge Editions: Paris, France 2003; p. 276.

[4] NHC Archive of Hurricane Seasons [homepage on the Internet], NOAA, Miami, Florida, USA. [Update 2009 May 11], Available from: http://www.nhc.noaa.gov/pastall.shtml.

[5] Zahibo N, Pelinovsky E, Talipova T, Rabinovich A, Kurkin A Nikolkina I. Statistical analysis of cyclone hazard for Guadeloupe, Lesser Antilles. J Atmos Res 2007; 84-1; 13-29.

[6] Zahibo N, Nikolkina I, Didenkulova I. Extreme ocean waves, extreme waves generated by cyclones in Guadeloupe. The Netherlands: Springer 2008; pp 159-77.

[7] Beven JL, Landsea C. Hurricane Omar, Tropical Cyclone Report, National Hurricane Center, 3 February 2009 [monograph on the internet] Available from: http://www.nhc.noaa.gov/2008atlan.-shtml

[8] Janssen P. The interaction of ocean waves and wind. Cambridge, UK: The University Press 2004; p. 89.

[9] Massel, SR. Ocean surface waves: Their physics and prediction. World Scientific: Singapore 1996; p. 300.

[10] Gonzalez FI, Milburn HM, Bernard EN, Newman JC. Deep-ocean Assessment and Reporting of Tsunamis (DART®): Brief Overview and Status Report. In Proceedings of the International Workshop on Tsunami Disaster Mitigation, 19-22 January 1998, Tokyo, Japan.

[11] GEBCO [homepage on the Internet]. Hosted by the British Oceanographic Data Centre (BODC), Liverpool, United Kingdom; [updated 2009 May 28][cited: 14 July 2009]. Available from: http://www.gebco.net/

[12] Kalnay E, Kanamitsu M, Baker WE. Global numerical weather prediction at the National Meteorological Center. Bull Am Meteorol Soc 1990; 71: 1410-28.

(c) Dorville and Zahibo; Licensee Bentham Open.

This is an open access article licensed under the terms of the Creative Commons Attribution Non-Commercial License (http://creativecommons.org/licenses/_by-nc/3.0/) which permits unrestricted, non-commercial use, distribution and reproduction in any medium, provided the work is properly cited. 